\title{
The Effects of the European Convention on Human Rights and the Strasbourg Case Law on the Development of Hungarian Law
}

\author{
BY MarCel SZABÓ*
}

\begin{abstract}
The European Convention on Human Rights is a milestone in the development of international law, aimed at guarding fundamental freedoms and human rights in Europe. As a consequence of the unique path of Central and Eastern European legal development, the provisions of the Convention and the case law of the European Court of Human Rights were not necessarily implemented into Hungarian law through the jurisprudence of Hungarian courts, but it was much rather the Constitutional Court who facilitated such implementation. Although the human rights protection system shaped by the European Court of Human Rights has now become an integral part of Hungarian law, the effect of the Convention and the Strasbourg case law on the Hungarian legal development is still rather meagre. The present article seeks to explore the possible reasons for this development.
\end{abstract}

Keywords: European Convention on Human Rights, jurisprudence of the European Court of Human Rights, Hungarian Constitutional Court, Hungarian legal development, implementation of the Strasbourg case law

\section{INTRODUCTION}

It has been twenty years since the most important constitutional document of the European human rights protection, namely the European Convention on Human Rights" ("the Convention") was promulgated by Act XXXI of 1993 entering into force on 15 April 1993 in Hungary. ${ }^{2}$ The Council of Europe was established with the aim to ensure European unity and to discover the common values which could serve as a sound basis for the cooperation between European peoples. The Council of Europe has contributed greatly toward unearthing the common values, establishing the foundation and the protection of such values.

Hungary signed the Convention on 6 November 1990 shortly after the first free elections took place and deposited the confirmation document on 5 November 1992. The Hungarian membership to the Convention commenced with a minor difficulty, the Convention only came into effect with respect to Hungary after six months following the deposit of the confirmation document. The Hungarian Constitutional Court referred to the

${ }^{1}$ Council of Europe, European Convention for the Protection of Human Rights and Fundamental Freedoms, 4 November 1950, ETS 5.

2 Pál Sonnevend, 'The Position of the European Convention on Human Rights in the Hungarian Legal Order' in Enver Hasani, Peter Paczolay and Michael Riegner (eds), Constitutional Justice in Southeast Europe: Constitutional Courts in Kosovo, Serbia, Albania and Hungary between Ordinary Judiciaries and the European Court of Human Rights (Deutsche Gesellschaft für Internationale Zusammenarbeit 2012) 166.

*Ombudsman for future generations, Office of the Commissioner for Fundamental Rights, Hungary. 
Convention several times before $1993^{3}$ and in the same year, prior to the accession to the Convention, the Constitutional Court specifically referred to the judgements of the Strasbourg European Court of Human Rights. ${ }^{4}$ At that time this "was a mere demonstration of exploring European standards", as László Sólyom, the former president of Hungary pointed out. $^{5}$

The Council of Europe and the Court were the torch-bearers of human rights in Europe at a time when Hungary suffered decades of Soviet oppression. Consequently, the Council of Europe represented the values that could not be enforced in Hungary between 1950 and 1990 for reasons of the dictatorial political system. This fuelled the expectation that the Hungarian legislation and jurisprudence will enthusiastically identify with the values and accept the human rights protection system shaped by the Court in the course of the previous decades. Ultimately it seems that the effect of the Court and the Convention on the Hungarian development of law is rather meagre. In the following sections I intend to explore the possible reasons for this development.

\section{THE NORMS OF STRASBOURG EUROPEAN HUMAN RIGHTS PROTECTION}

We must draw a distinction between different legal categories when analysing the effects of the Convention and the Strasbourg case law on the Hungarian development of law:

\subsection{European Convention on Human Rights}

As the Convention has become part of Hungarian domestic law, the provisions of the Convention are binding on all Hungarian legal entities. Before the Fundamental Law of Hungary entered into force in 2012 the previous Hungarian constitution merely prescribed the consistency between international law and domestic law as a constitutional criterion. ${ }^{6}$ The priority of international agreements over Hungarian legislation could be deduced from the provisions of the Constitutional Court Act according to which the Constitutional Court had the right to annul acts contravening international agreements. ${ }^{7}$ By comparison, the new Fundamental Law of Hungary accommodates public international law by clarifying that

3 The Constitutional Court referred to the European Convention on Human Rights for the first time in its Decision No. 23/1990 (X. 31.) (ABH 1990, 88.) in 1990, one week before the signing of the Convention.

4 The Hungarian Constitutional Court declared in its Decision No. 64/1993 (XII. 22.) (ABH 1993, 379-382) that its interpretation on the protection of property is in accordance with the provisions of the European Convention on Human Rights and the jurisprudence of the European Court of Human Rights. See László Sólyom, Az alkotmánybíráskodás kezdetei Magyarországon [The Beginnings of Constitutional Jurisdiction in Hungary] (Osiris 2001) 640.

5 László Sólyom, 'Kölcsönhatás az Emberi Jogok Európai Bíróságának esetjoga és a szólásszabadság védelme között Magyarországon' [Interaction between the Jurisprudence of the European Court of Human Rights and the Protection of the Freedom of Speech in Hungary] (1996) 97/3-4 Állam- és Jogtudomány 151.

${ }^{6}$ See Article 7 paragraph 1 of Act XX of 1949 on the Constitution of the Hungarian Republic.

7 See Article 42 paragraph 1 of Act CLI of 2011 on the Constitutional Court (previously Article 45 of Act XXXII of 1989). 
promulgated international agreements enjoy priority over domestic Hungarian laws and other legal instruments. ${ }^{8}$

According to the Constitutional Court in case of conflict the Constitution shall prevail ${ }^{9}$ over the international agreements. ${ }^{10}$ As Peter Kovács also underlines in respect of the hierarchy of norms, the Convention in the Hungarian constitutional legal order is subordinated to the constitution, however, it enjoys a higher position in comparison to domestic laws and other legal instruments. ${ }^{11}$ Naturally, this concept was applicable to the period prior to the entry into force of the Fundamental Law. Article 7 paragraph 1 of the former Constitution set out the requirement of consistency between international and domestic law. The Constitutional Court ensured compliance with this constitutional requirement by interpreting the provisions of the Constitution in accordance with the rules of international law, ${ }^{12}$ but it could not annul the provisions of the Constitution. ${ }^{13}$ Péter Kovács believes that the rules of the Convention are quasi equivalent to the fundamental provisions of Fundamental Law and pursuant to the imperative logic and expedience of the Convention he emphasizes that the respective rules of the Fundamental Law should be interpreted in light of the Strasbourg case law. ${ }^{14}$ In case consistency cannot be ensured between international obligations and the Fundamental Law, the legislator is responsible for ensuring this harmony even through the amendment ${ }^{15}$ of the Fundamental Law. ${ }^{16}$

\subsection{Cases to which Hungary was a party}

As a signatory to the Convention, Hungary is obliged to enforce judgments to which Hungary is a party. The vast majority of the judgments declare that the domestic legal act or procedure under scrutiny is contrary to the human rights norms applied in Strasbourg, moreover, as a specific obligation the judgment also prescribes the payment of damages to the injured private party. The Court in Strasbourg has no formal power to legally oblige Hungary to amend domestic law. The primary aim of the states concerned shall be the

8 See Article Q paragraph 3 of the Fundamental Law.

9 Péter Kovács stresses that the norms of jus cogens prevail over the rules of the Constitution. Péter Kovács, 'La collision d'une norme constitutionnelle et du droit international dans la pratique de la Cour Constitutionnelle hongroise' (2010) 7/1 Miskolc Journal of International Law 19.

10 This perspective may have been motivated by the approach that in the process of the conclusion of international agreements there are several possible means to amend the Constitution, even by a mandate which does not achieve the degree of constitutional majority. Constitutional Decision No. 30/1998 (VI.25.) on the Europe Agreement declares that the Constitution cannot be amended by the conclusion of an international agreement.

11 Kovács 16.

12 Constitutional Decision No. 53/1993 (X.13.) ABH 1993, 327. Gábor Magyar also emphasizes that the text of the Constitution in force should be analysed and interpreted in the light of the Strasbourg case law. Furthermore, he adds that the Constitutional Court only has the right to determine a constitutional requirement if the international agreement and the Fundamental Law are inconsistent. Gábor Magyar, 'Strasbourg és a magyar joggyakorlat' [Strasbourg and the Hungarian Jurisprudence] (2005) 1 Fundamentum 51

13 Constitutional Decision No. 23/1994 (IV. 29.) ABH 1994, 375, 376; Constitutional Decision No. 293/B/1994 ABH 1994, 862.

14 Kovács 20.

15 Constitutional Decision No. 4/1997 (I.22.) ABH 1997, 52.

16 Kovács 18. 
prevention of further infringements by amending their relevant domestic law. Several states, particularly Italy ${ }^{17}$ illustrate well that in the face of multitudinous claims concerning identical infringements, the state is forced to amend its laws that infringe human rights. ${ }^{18}$

Hungary in cooperation with some other states hampered the amendment to the procedural rules of the Court which would have allowed the Court to act as a quasi constitutional court and to expand the focus of the judgment from the concrete individual case to a more general one, with the result that the Court could have had the right to reject cases it deems less significant. ${ }^{19}$ This solution was found unacceptable by Hungary and some other states, since it may jeopardize the effectiveness of the international system of legal protection. Consequently, the enforcement of the Court's judgments in the national legal system is of particular relevance to us in accordance with the compromise solution set out in Protocol 14, stressing the responsibility of the member states in guaranteeing human rights through the national system of legal protection. ${ }^{20}$

\subsection{Legal Principles Developed in the Jurisprudence of the European Court of Human Rights}

It is uncommon in international legal literature to refer to legal principles developed by the Court without referring to the judgments. It must be pointed out that with Hungary's accession to the European Union, Hungary became the member of two communities of values, both concurrently imposing legal obligations on the state. Hungary is not only a member of the Council of Europe but is also a member state of the European Union. In the framework of European law the legal principles developed by the Court are considered primary law sources. In this respect, the legal principles developed by the Court have priority over domestic law pursuant to the hierarchy of norms of the European Union and the binding application of such principles is required by the European Union of all judicial forums and executive bodies.

At this point it is worth mentioning that the principles developed by the Court in Strasbourg also constitute the general principles of the European Union, therefore, following Hungary's accession to the European Union we are obliged to apply and enforce such principles in our national legal order. In my opinion, the mandatory effect of the general principles developed in the Strasbourg case law flows from the legal force attached to it by European law.

17 The European Court of Justice in its judgement in the Sejdovic v. Italy case declared that the Italian Code of Criminal Procedure raises systemic problems connected to the malfunctioning of domestic legislation as it fails to ensure the possibility to reopen proceedings conducted in the accused's absence, irrespective of the fact that the accused has been properly informed about the proceedings. ECtHR: Sejdovic v. Italy (Application no. 56581/00) Strasbourg, Judgment of 1 March 2006 para. 5.

18 Csaba Pákozdy, 'The Relation between the Judgements of the European Court of Human Rights and the National Law in Hungary' (2006) 3/3 Miskolc Journal of International Law 85.

19 Mónika Weller, 'Az európai emberi jogi rendszer reformja: egy új elfogadhatósági kritérium' [The Reform of the European Human Rights System: A New Acceptance Criteria] (2004) 4 Acta Humana 88.

20 ibid 61. 


\subsection{Judgements of the European Court of Human Rights concerning other Member States}

The provisions of the Convention were unfolded by the Court in its numerous judgments, resulting in a comprehensive system of human rights protection. As regards the legal position of these judgments in the Hungarian domestic order, different approaches exist. ${ }^{21}$ According to one approach the practice of the Court is constantly evolving, thus, it should not be continuously compared to the Hungarian domestic legal order. Accordingly, the case law of the Court should merely serve as a complementary method substantiating the best alternative among the possible solutions provided for under the domestic law. ${ }^{22}$ Nevertheless, we may also assume that by becoming a signatory to the Convention, Hungary became a member of a community of law and through its judgments the Court constantly shapes the rules of this legal community. Therefore, Hungary shall consider these judgements as precedents and standards. ${ }^{23}$ According to Tamás Bán, the correct interpretation and application of the case law may only be achieved if we deduct the conclusions of certain judgments and apply them to our own legal system, even if Hungary was not party to the procedure. According to Bán this follows from the principle of pacta sunt servanda and the principle of performing international obligations in good faith. ${ }^{24}$ Pursuant to Article 1 of the Convention, the contracting parties shall provide each individual under their respective jurisdiction the enjoyment of rights and freedoms determined under the Convention, furthermore, these rights must be afforded the interpretation reflected in the decisions of the Court. ${ }^{25}$ Strasbourg case law thus unfolds the specific content of the rights, deducting possible restrictions of fundamental rights as well as the respective tests from the text of the Convention. ${ }^{26}$ As a result, we must also follow judgments to which we are not a party. This follows from Article 46 paragraph 1 of the Convention according to which the High Contracting Parties undertake to abide by the final judgment of the Court in any case to which they are parties. The other important provision is Article 32 paragraph 1 according to which the jurisdiction of the Court shall extend to all matters concerning the interpretation and application of the Convention and the Protocols thereto. ${ }^{27}$

21 Some authors state that the case law of the Court may serve only as a source of inspiration while according to others the Court's case law has a binding effect. See Sonnevend 169-170.

${ }^{22}$ For instance, László Blutman stresses that the Court's reasoning may serve as a justificatory or complementary constitutive argument but should not be a decisive constitutive argument, since according to Article 46 of the Convention the judgements of the Court do not have formal normative power. In its decision No. 18/2004 (V. 25.) the Constitutional Court declared that the approach of the Court constructs and obliges the Hungarian legal practice. László Blutman emphasises that this is not applied to certain judgements but rather to the concept itself, namely to the Strasbourg case law in a broader sense. See László Blutman, 'A nemzetközi jog használata az Alkotmány értelmezésénél' [The Use of International Law in Constitutional Interpretation] (2009) 64/7-8 Jogtudományi Közlöny 308-310.

23 Christoph Grabenwarter, Europäische Menschenrechtskonvention (2nd edn, Beck 2005) 98.

24 Tamás Bán, 'Strasbourg és a magyar joggyakorlat' [Strasbourg and the Hungarian Jurisprudence] (2005) 1 Fundamentum 49.

25 Zoltán Tallódi, 'Strasbourg és a magyar joggyakorlat' [Strasbourg and the Hungarian Jurisprudence] (2005) 1 Fundamentum 55.

26 Bán (2005) 48.

27 ibid 47. 
It is worth highlighting the Fratanoló case ${ }^{28}$ from among the many judgements of the Court rendered in relation to Hungary - a case that gave rise to grave concerns in our country, many believe that the Court did not take into account the unique process of legal development that took place in Central and Eastern Europe, including the resentment towards the use of red star. Some scholars stressed that in the Rekvényi case, ${ }^{29}$ which was one of the most important Strasbourg judgments from the perspective of Hungary, the Court gave due consideration to the demand arising in Central and Eastern European states that policemen who were actively involved in sustaining the totalitarian, one-party state, should not be allowed to continue their activities in political parties. ${ }^{30}$ The shockwaves of the Fratanoló case reached the Hungarian Parliament, which adopted a resolution protesting against the final judgement, at the same time, it was clear that Hungary would enforce the judgment. Although the case received significant media coverage, what is more important is that the Hungarian Parliament has already passed the amendment to the relevant domestic law to ensure conformity with the judgment of the Court.

The Hungarian Parliament is committed to taking into consideration the developments in the Strasbourg jurisprudence even in cases that fail to awaken citizens' interest. The provisions of our previous Constitution and our current Fundamental Law with respect to the voting rights of the prisoners could serve as a good example. Our Fundamental Law may have been decisively influenced by the judgement of the European Court of Justice rendered in the Hirst case, ${ }^{31}$ according to which not all persons sentenced to imprisonment are excluded from voting, ${ }^{32}$ but only those who had been excluded from involvement in public affairs by final judgment of the domestic court. ${ }^{33}$

\subsection{Recommendations of the Council of Europe}

The Council of Europe adopts recommendations in respect of the specific rights protected under the Convention and these recommendations may be understood as interpretations and detailed clarifications of the Convention. According to some authors, Hungary should consider these recommendations as soft law norms making up the foundation of the European system of human rights protection, since they may underpin the argumentation of the Constitutional Court $^{34}$ or serve the reasonable justification of the judgements. It is nevertheless an important question, whether a reference to soft law international documents may imply a duty to respect or apply these norms. ${ }^{35}$ In this regard, László Blutman draws

28 ECtHR: Fratanoló v. Hungary (Application no. 29459/10) Strasbourg, Judgment of 3 November 2011

29 ECtHR: Rekvényi v. Hungary (Application no. 25390/94) Strasbourg, Judgment of 20 May 1999 [1999] ECHR 31.

30 Tamás Bán, 'A Rekvényi-ügy és környéke' [The Rekvényi Case and Its Vicinity] (1999) 3 Fundamentum 94.

31 ECtHR: Hirst v. the United Kingdom (No 2) (Application no. 74025/01) Strasbourg, Judgment of 6 October 2005 [2005] ECHR 681.

32 See Section 5 of Article 70 of Act XX of 1949 on the Constitution of the Hungarian Republic.

33 See Section 6 of Article XXIII of the Fundamental Law.

34 See e.g. Constitutional Decision No. 19/1999 (VI.1) (judicial independence), ABH 1999, p. 150, Section II. 1. 2.

35 Blutman (2009) 302-304. Cf. Constitutional Decision No. 45/2005 (XII. 14.) (certain rights of national and ethnic minorities), ABH 2005, p. 569, Péter Kovács (concurring opinion) Section III/2/1. 
attention to the worrisome practice when the Constitutional Court determines the content of the rights set out in the Constitution exclusively on the basis of the recommendations issued by the Committee of Ministers of the Council of Europe. This means that in the course of determining the content of certain constitutional provisions the Constitutional Court invokes a non-binding international soft law norm as a constitutive norm. ${ }^{36}$

\section{THE POSSIBILITY OF INVOKING STRASBOURG NORMS}

Above, I attempted to draw a distinction between the different Strasbourg norms and other complementary instruments of the European system of human rights protection. Below I shall explore the institutions and persons entitled to draw attention to discrepancies between the Strasbourg case law and domestic law.

\subsection{Petitioning the Constitutional Court}

Given that the Convention forms part of the domestic legal order, Hungarian natural and legal persons are entitled to claim their rights stemming from the Convention before national courts. Persons may also complement their arguments with references to judgments unfolded and interpreted in detail by the Court in its jurisprudence, regardless of whether Hungary was a party to the proceedings in the framework of which the judgement was adopted.

However, Hungarian judicial forums do not have the right to disapply the domestic law in case its provisions appear to be contrary to those of the Convention. In such cases, the courts shall request the Constitutional Court to assess and adjudge the conflict of norms. ${ }^{37}$ As such, any reference to the case law of the Court or to the Convention itself shall primarily serve the definition of the scope and possible restriction of fundamental rights set out in the Hungarian Fundamental Law on the basis of the provisions of the Convention and case law of the Court.

\subsection{Submissions to the Constitutional Court by lower instance courts}

The Hungarian courts may observe ex officio and not solely upon the request of a private individual that a law is contrary to the case law of the Court or the provisions of the Convention. In this case domestic courts may ex officio seek remedy from the Constitutional Court and request the resolution of the conflict of norms.

\subsection{Ex officio procedure of the Constitutional Court}

The Constitutional Court is bound by the Fundamental Law and may therefore not annul its provisions. However, in case the provisions of the Convention and the Fundamental Law are in contravention, the Constitutional Court may call the legislator's attention to such an inconsistency. The Parliament has the authority to resolve the inconsistency observed by the

36 Blutman (2009) 312 .

${ }^{37}$ According to Article 32 paragraph 2 of Act CLI of 2011 on the Constitutional Court "[j]udges shall suspend judicial proceedings and initiate Constitutional Court proceedings if, in the course of the adjudication of a concrete case, they are bound to apply a legal act that they perceive to be contrary to an international treaty." 
Constitutional Court even by means of amending the Fundamental Law ${ }^{38}$ since providing for harmony with international law constitutes an essential duty of the Parliament prescribed by the Fundamental law. ${ }^{39}$

\subsection{Preliminary assessment of draft legislations by the Ministry of Public Administration and Justice}

It is the duty of governmental representatives working in the Ministry of Public Administration and Justice to perform the preliminary assessment of draft legislation in the light of the Convention and the Strasbourg case-law and to indicate to the legislator in case they arrive at the conclusion that draft legislation is contrary to these sources. ${ }^{40}$

Based on the above we may state that there are certain institutions and actors in the Hungarian legal order that are responsible for ensuring the harmonised, consistent and effective implementation of the provision of the Convention and the case law of the Court into domestic law, either in the framework of their constitutional duties or their authority of enforcement. Below I will examine how relevant procedural rules and legal theory may facilitate the effective enforcement carried out by such actors.

\section{NATIONAL FORUMS OF LEGAL ENFORCEMENT}

\subsection{Ordinary courts}

As far as the enforcement of Strasbourg human rights principles are concerned, the Hungarian judicial system is not part of the solution but much rather a part of the problem, at least from the perspective of the citizens. A significant portion of the successful cases before the Court are premised on the principle of due process breached by the lengthy procedures of domestic courts. The number of claims submitted against Hungary has increased year by year, there are more and more well-founded claims and over one quarter of admissible actions connected to the breach of Article 6 of the Convention. ${ }^{41}$ Hungarian courts play a minor role in resolving anomalies of the domestic legal system pursuant to the principles formed by the Court, for, as pointed out above, domestic courts cannot arrive at a contra legem interpretation of Hungarian law. Nevertheless, the jurisprudence of the European Court of Human Rights of the past decades has helped clarify the content of several fundamental rights, therefore, the legal principles developed by the Court or the precedents ensuing from the concrete judgments may inspire praeter legem interpretation.

Hungarian ordinary courts are reluctant to found their decisions on the Fundamental Law and its fundamental rights provisions. They merely refer to constitutional principles as supplementary arguments and they almost never mention human rights which are set out in international treaties. ${ }^{42}$ As Gábor Magyar highlighted in his research, of all the judgments

38 See Section 2 of Article 42 of Act CLI of 2011 on the Constitutional Court.

39 See Section 2 of Article Q of the Fundamental Law.

40 Tallódi 56-57.

${ }^{41}$ Anikó Szalai, ‘Az Emberi Jogok Európai Bírósága ítélkezésének megjelenése a magyar Alkotmánybíróság gyakorlatában' [The Emergence of the Jurisprudence of the European Court of Human Rights in the Practice of the Hungarian Constitutional Court] (2010) 7/4 Kül-Világ 16.

${ }^{42}$ László Blutman, ‘A nemzetközi jog a magyar bírósági joggyakorlatban’ [International Law in the Judicial Practice of the Hungarian Courts] in Károly Tóth (ed.), In memoriam Nagy Károly (19322001) (SZTE-ÁJK 2002) 44. 
adopted in the entire domestic judicial system between 1992 and 2004, there were only 4 judgements where the Convention and the practice of the Court had a major influence on the final decision. ${ }^{43}$ Furthermore, we are not aware of any judgement where the local or county court presumed a conflict between Strasbourg law and domestic law, referring the case to the Constitutional Court to resolve such conflict. As such, we may say that the contribution of the domestic judicial system to the enforcement of the Convention and the related case law of the Court is rather minimal.

In several European states active citizens have profoundly contributed to the implementation of Strasbourg case law into the domestic legal system, supported by the judicial forums in the legal enforcement process. According to the typical position of domestic courts, the Hungarian legislator is the one responsible for ensuring conformity between Strasbourg law and domestic law. National judges restrict themselves to applying the provisions of the domestic legal order and expect the legislator to deal with the implementation of international rules into the Hungarian law. In this context, Mónika Weller draws attention to the significance of acts of the court, since these are considered as imputable to the state under international law, capable of giving rise to the international liability of the state in case of infringement. ${ }^{44}$ It is worth mentioning the legal tradition characteristic of Central and Eastern Europe, according to which for several decades constitutional law - as a quasi legal window dressing - had no veritable connection to domestic criminal or civil law, rendering it a heresy for the party to invoke constitutional rights before the court. As a result, traditions of human rights protection could only be established following the political change. It would be extremely demanding for domestic courts to take into consideration judgments in the course of the assessment of cases related to fundamental rights which are predominantly unavailable in the Hungarian language and which are so complexly framed, that their system is not necessarily accessible for Hungarian judges. At the same time, the short summaries of certain judgments available in Hungarian are often oversimplified and capable of misleading national judges into drawing false analogies. With the extension of the material scope of the Convention and the determination of new forms of infringements, the Strasbourg Court is taking a strict stance making it even more difficult for national courts to continuously follow Strasbourg jurisprudence. ${ }^{45}$ Moreover, even the Strasbourg Court fails to precisely follow its own jurisprudence. Therefore, the cautious attitude of domestic courts towards the human rights related guidance of the European Court of Human Rights is neither unjustified nor to be condemned; at the same time, we can only hope that with time, this reserved approach will change.

\subsection{Constitutional Court}

The implementation of the values developed by the Court was predominantly carried out by the Constitutional Court in the domestic context. Government representatives as supporting experts also facilitated this mediation process, albeit their work was not accessible to the public. In theory, a case concerning the Convention or the practice of the Court may be brought before the Constitutional Court in two ways. Firstly, a case may concern the conflict between international law and Hungarian law. According to our international obligations and constitutional provisions, the Strasbourg law prevails over the domestic law. Although

\footnotetext{
43 Magyar 49.

44 Mónika Weller, 'Strasbourg és a magyar joggyakorlat' (2005) 1 Fundamentum 59.

45 Magyar 52.
} 
it is the Constitutional Court that is entitled ${ }^{46}$ to assess the conflict of domestic law and international law and is empowered to annul legal acts contrary to national law promulgating an international treaty ${ }^{47}$ the Act on the Constitutional Court has regulated the scope of persons entitled to launch such proceedings so restrictively ${ }^{48}$ that it is almost impossible to bring a case before the Constitutional Court via this route.

The Strasbourg law may further become the subject of consideration by the Constitutional Court in the case where this major judicial forum seeks international examples and inspirations for the clarification of the framework of domestic constitutional norms. Although the Fundamental Law was inspired predominantly by the Universal Declaration of Human Rights and the International Covenant on Civil and Political Rights, ${ }^{49}$ taking into account the universal nature of human rights a significant number of the aforementioned international treaties' provisions are also enshrined in the Convention. Moreover, the remarkably productive jurisprudence of the Court enabled the domestic development of several principles and solutions. If the Constitutional Court deems necessary it boldly draws inspiration from these principles in order to support its reasoning.

László Blutman points out that it would be counterproductive if the judgements of the Court could serve as exclusive arguments and in his opinion this would even be incompatible with our legal order. Blutman stresses that Strasbourg case law is complementary in nature, however, the supporting effects of these judgements are undeniable..$^{50}$ The decisions of the European Court of Justice may shield the argumentation of the Constitutional Court in cases where the text of the Constitution does not provide sufficient hold..$^{51}$ For instance, in a case $^{52}$ regarding the constitutionality of restrictions on the acquisition of agricultural lands, the forum referred to the Marckx case adopted on 13 June 1976 and to an unpublished opinion of the European Commission of Human Rights. In its judgement the European Court of Justice declared that the right to property is not extended to the acquisition of property as only already acquired property enjoys this type of legal protection. ${ }^{53}$

46 See Point $f$ ) of Section 2 of Article 24 of the Fundamental Law.

47 According to Article 42 of Act CLI of 2011 on the Constitutional Court, if the Constitutional Court "declares that a legal act is contrary to an international treaty which, according to the Fundamental Law, shall not be in conflict with the act promulgating the international treaty", then the Constitutional Court is entitled to annul the contravening act. Nevertheless, if the Constitutional Court declares that such a legal act is contrary to an international treaty, with which, according to the Fundamental Law, the legal act promulgating the international treaty shall not be in conflict, it shall request the Government or the legislator to commence the necessary measures in order to resolve the conflict.

48 According to Section 2 of Article 32 of Act CLI of 2011 on the Constitutional Court " $[t]$ he proceedings may be requested by one quarter of Members of Parliament, the Government, the President of the Curia, the Prosecutor General or the Commissioner for Fundamental Rights".

49 Tamás Molnár, 'Az európai jogfejlődés hatása a magyar alkotmányfejlődésre' [Effect of the European Legal Development on the Hungarian Constitutional Development] (2005) 16/2 Acta Humana 58

${ }^{50}$ Blutman (2009) 308

51 Molnár 62.

52 Constitutional Decision No. 35/1994 (VI. 24.) AJBH 1994, p. 197.

53 Sólyom (1996) 154; Molnár (n 49) 61. 
We can say the following about the attitude of the Constitutional Court towards the Strasbourg case law:

a.) First, the Constitutional Court does not intend to make it unambiguous that it applies the case law of the Court, not even in situations when this may be inferred from other circumstances. ${ }^{54}$ For instance, in the Bukta case ${ }^{55}$ the Constitutional Court utilises the logic of the Court in the domestic procedure regarding the annulment of the act concerned by merely mentioning the Court as one of the sources of the legal arguments presented.

b.) Second, besides the Convention the Constitutional Court also interprets the complementary Protocols and in certain cases it even expands beyond the concept the Strasbourg Court would attribute to the provision concerned, as it happened in the case of the decision regarding religious freedom and the state's obligation of establishing and maintaining public institutions. ${ }^{56}$

c.) Third, although the Constitutional Court is influenced by the basic principles developed by the Court, the Constitutional Court may not necessarily pay attention to the distinctions elaborated in each and every specific Strasbourg case or the further refinement of such principles. In some cases the Constitutional Court refers to particular cases as the main authority in a given field, notwithstanding the fact that scholarly literature would point to other judgments in the case concerned.

d.) Fourth, besides the text of the Convention and the respective case law, the Constitutional Court also takes into consideration, where appropriate, the recommendations of the Council of Europe in order to unfold the contents of certain fundamental rights. ${ }^{57}$

The main achievement of the Constitutional Court in relation to the Strasbourg law is that it supplemented our Fundamental Law - previously our Constitution - on the basis of the values enshrined in the Convention and further developed through Strasbourg jurisprudence, rendering these sources a benchmark in the protection of fundamental rights. One of the most important domestic judgements in this respect is perhaps the recognition of the freedom to conclude a marriage as a constitutional right with reference to the Convention. ${ }^{58}$ The recognition of this right is a novelty, especially if we consider that our previous constitution protected the institution of marriage and family ${ }^{59}$ but it did not set forth the conclusion of marriages as a fundamental right.

54 Szalai 14

55 ECtHR: Bukta and others v. Hungary (Application no. 25691/04) Strasbourg, Judgment of 17 July 2007. 51 EHHR 25 .

56 By referring to Article 2 of Protocol 1 of the Convention, the Constitutional Court laid down in its Decision No. 4/1993 (II. 12.) (ABH 1993, p. 54.) that the positive duties of the state to ensure the freedom of religion go beyond the obligations stipulated by Act IV of 1990 on the Freedom of Conscience and Religion. Hungary undertook further obligations under international conventions, thus, beyond its duty to provide neutral education it must also ensure the legal and material conditions necessary for the establishment of religious schools. See Molnár 62.

57 See e.g. Constitutional Decision No. 41/2005 (X.27.) (autonomy of higher education institutions) ABH 2005, 459, Péter Kovács (concurring opinion).

58 The right to conclude a marriage pursuant to Article 12 of the Convention was deducted by the Constitutional Court on the basis of Article 7 paragraph 1 of the former Constitution which set out the consistency requirement between international law and domestic law in order to provide for the freedom to conclude a marriage. Constitutional Court Decision No. 22/1992 (IV. 10.) ABH 1993, 54.

59 See Article L of the Fundamental Law (previously Article 15 of Act XX of 1949 on the Constitution of the Hungarian Republic). 
In conclusion we may say that as a result of the Constitutional Court's efforts, the Strasbourg case law has become a complementary means of substantiating, clarifying and determining the content of constitutional rights. However, the highest judicial forum does not refer typically to the possibility of conflict of international and domestic norms but applies the Strasbourg case law as a benchmark for the interpretation of fundamental rights instead. ${ }^{60}$

\section{SUMMARY}

The Convention is the most important constitutional document in Europe. International treaties, including the Convention and the related case law of the Court occupy a favourable position in the Hungarian hierarchy of norms. However, the ideal status of the Convention would be if it were on equal footing with Hungarian constitutional provisions. Pursuant to our current legal system and to the practice of the Constitutional Court, the Convention ranks below the Constitution but above other sources of domestic law. Although the status of the Convention in the hierarchy of norms in Western states is similar to that in the Hungarian approach, a shift in this constitutional approach would nevertheless be desirable. It is worth noting that the Dutch Constitution ${ }^{61}$ provides constitutional rank to the Convention, moreover, the Austrian Fundamental Law ${ }^{62}$ explicitly makes the Convention part of constitution. The Constitution of Kosovo ${ }^{63}$ goes even further by declaring the requirement of consistency of the Constitution with Strasbourg case law. ${ }^{64}$

The standards set by the Court have become part of the civil attitude and the civilian way of thinking in many cases. Suffice to refer to a principle developed by the Court according to which public figures must tolerate more than other citizens in the context of others' exercise of their freedom of expression; today, this principle is no longer a legal benchmark but has become part of the everyday attitude of Hungarian citizens. ${ }^{65}$

As an outcome of the unique path of Central and Eastern European legal development, the provisions of the Convention and case law of the Court are not necessarily implemented into domestic law through the judicial practise of domestic judges, but it is much rather the Constitutional Court who facilitated such implementation. The clarification of fundamental rights by the Constitutional Court and the work of Hungarian governmental representatives in Strasbourg helped fuel this procedure. Generally speaking it may be said that, albeit as a result of various efforts, in the course of the last 20 years the Strasbourg jurisprudence has become an integral part of Hungarian law. This gives rise to the hope that the means of legal enforcement and the conscious commitment to the Convention and the related case law of the Court will gain even more impetus in Hungary in the future.

${ }^{60}$ As László Blutman observes, the doctrine of constitutional interpretation in accordance with the generally accepted rules of international law has been developed in the practice of the Constitutional Court. Blutman (2009) 310.

${ }^{61}$ Peter Van Dijk et al. (eds), Theory and Practice of the European Convention on Human Rights, (4th edn, Intersentia 2006) 27.

62 Art. II. 7 of Bundesverfassungsgesetz (BGB1. 59/1964).

${ }^{63}$ Article 53 of the Constitution of Kosovo.

64 Sonnevend 166-167.

65 Tallódi 57. 


\section{LITERATURE}

Bán, T., ‘A Rekvényi-ügy és környéke’ [The Rekvényi Case and Its Vicinity] (1999) 3 Fundamentum 94-100.

Bán, T., 'Strasbourg és a magyar joggyakorlat' [Strasbourg and the Hungarian Jurisprudence] (2005) 1 Fundamentum 47-53.

Blutman, L., 'A nemzetközi jog a magyar bíróságok gyakorlatában' [International Law in the Judicial Practice of the Hungarian Courts] in Tóth, K. (ed.), In memoriam Nagy Károly (1932-2001) (SZTE-ÁJK 2002) 41-53.

Blutman, L., 'A nemzetközi jog használata az Alkotmány értelmezésénél' [The Use of International Law in Constitutional Interpretation] (2009) 64/7-8 Jogtudományi Közlöny 302-312.

Grabenwarter, Ch., Europäische Menschenrechtskonvention (2nd edn, Beck 2005).

Kovács, P., 'La collision d'une norme constitutionnelle et du droit international dans la pratique de la Cour Constitutionnelle hongroise' (2010) 7/1 Miskolc Journal of International Law 16-20.

Magyar, G., 'Strasbourg és a magyar joggyakorlat' [Strasbourg and the Hungarian Jurisprudence] (2005) 1 Fundamentum 49-53.

Molnár, T., 'Az európai jogfejlődés hatása a magyar alkotmányfejlődésre' [Effect of the European Legal Development on the Hungarian Constitutional Development] (2005) 16/2 Acta Humana $57-63$.

Pákozdy, Cs., 'The Relation between the Judgements of the European Court of Human Rights and the National Law in Hungary' (2006) 3/3 Miskolc Journal of International Law 73-84.

Tallódi, Z., 'Strasbourg és a magyar joggyakorlat' [Strasbourg and the Hungarian Jurisprudence] (2005) 1 Fundamentum 54-58.

Sonnevend, P., 'The Position of the European Convention on Human Rights in the Hungarian Legal Order' in Hasani, E., Paczolay, P. and Riegner, R. (eds), Constitutional Justice in Southeast Europe: Constitutional Courts in Kosovo, Serbia, Albania and Hungary between Ordinary Judiciaries and the European Court of Human Rights (Deutsche Gesellschaft für Internationale Zusammenarbeit 2012) 163-173.

Sólyom, L., Az alkotmánybíráskodás kezdetei Magyarországon, [The Beginnings of Constitutional Jurisdiction in Hungary] (Osiris 2001).

Sólyom, L., 'Kölcsönhatás az Emberi Jogok Európai Bíróságának esetjoga és a szólásszabadság védelme között Magyarországon' [Interaction between the Jurisprudence of the European Court of Human Rights and the Protection of the Freedom of Speech in Hungary] (1996) 97/3-4 Államés Jogtudomány 149-172.

Szalai, A., ‘Az Emberi Jogok Európai Bírósága ítélkezésének megjelenése a magyar Alkotmánybíróság gyakorlatában' [The Emergence of the Jurisprudence of the European Court of Human Rights in the Practice of the Hungarian Constitutional Court] (2010) 7/4 Kül-Világ 14-21.

Van Dijk, P. et al. (eds), Theory and Practice of the European Convention on Human Rights, (4th edn, Intersentia 2006).

Weller, M., ‘Az európai emberi jogi rendszer reformja: egy új elfogadhatósági kritérium’ [The Reform of the European Human Right System: A New Acceptance Criteria] (2004) 4 Acta Humana 7888.

Weller, M., 'Strasbourg és a magyar joggyakorlat' (2005) 1 Fundamentum 59-61. 